\title{
LOCAL BOONS: \\ THE MANY LIVES OF FAMILY STORIES
}

\author{
KIRIN NARAYAN
}

"Why did she never tell us this?" My stunned aunt Chanda-phui turned to look again at the small, brightly painted Shiva temple in the Kathiawar peninsula of Gujarat, western India. Moments before, a gray haired stranger had ambled in through the temple gate, settled on a ledge, and casually narrated the founding legend of this village temple: a legend that featured Chandaphui's mother, my grandmother Ba. This soft-spoken man had most likely not imagined that he would be addressing Ba's descendents to explode over eighty years of silence and unsettle our conceptions of ancestral identity.

I position this unexpected revelation at the heart of my essay to consider the role of family stories in self-narrations. Even before I studied cultural anthropology or folklore, I had delighted in stories; a scholarly training gave me further reasons to work with oral narratives of many genres, including family stories. Across the years, I have come to appreciate how even as personal narratives are culturally shaped in form, theme, and performance style, collectively shared narratives are personalized around particular sensibilities and experiences (cf. Narayan, "Honor," Mondays, Storytellers; Narayan and George). Here, I summarize some of the mythically contextualized reminiscences told by the feisty woman I was lucky to know as a grandmother. I juxtapose her self-narrations to the alternate life stories lodged in court documents and the local legend of a temple's founding. I consider all these accounts part of my family stories. In presenting them here, I argue for the analytic value of reflecting on the powerful intersubjective space of family stories in considering cultural—and multicultural—self-images in life stories.

By family story, I mean stories told by or about family members, though there is clearly a wide and culturally inflected range to who is included in the family and the kinds of stories that are told. As the historians Daniel Bertaux and Paul Thompson observe in their edited volume Between Generations: Family Models, Myths and Memories, "Family' is a cultural image constructed out of real individuals, and also, sometimes, mythical ancestry" (2). Family 
stories can include rehashings of recent events that the speaker may have personally observed; oral history and legends about ancestors that are passed along through generations; and also myths that index a family's relationship to supernatural or divine beings. Family stories offer family members a personalized connection to places and to history. In India, the presence of caste bards, the Bhats or Charans, also extend family stories into a more formalized arena (cf. Bhatnagar et al.; Shah and Shroff; Snodgrass).

Folklorists and anthropologists with training in folklore (Boatright; Brandes; Morgan; Zeitlin, Kotkin and Baker), oral historians (Bertaux and Thompson), developmental psychologists (Fiese et al.; Pratt and Fiese), and scholars of communication (Langellier and Peterson; Trujillo) have all written in various ways about family stories as a means of transmitting identities. A more interdisciplinary and accessible account, Black Sheep and Kissing Cousins: How Family Stories Shape Us, by Elizabeth Stone, has been reprinted in several editions since it first appeared in 1988. For many scholars though, family stories may seem a lightweight interest, particularly if these stories are one's own: something more appropriate to dinner tables than seminar rooms, conferences, or publications.

For cultural anthropologists, family stories are largely an unmarked analytic category: certainly, other people's family stories appear in life histories, oral histories, and even ethnographic accounts, but they are usually shuffled in amid other sorts of narrative data. Occasionally, in prefaces or acknowledgments, anthropologists acknowledge their own family backgrounds as the source of scholarly interest. With a growing acceptance of more reflexive and auto-ethnographic approaches, anthropologists' own family stories increasingly surface into publication, whether in memoirs (Bateson; Orlove; Welland), or as woven through essays or ethnographies relating to the themes of the family stories (Abu-Lughod; Behar; Waterson and Rylko-Bauer). A powerful 2005 issue of Anthropological Quarterly focused on four anthropologists' family stories of holocaust, exile, and diaspora; as Paul Farmer pointed out in his commentary on that issue, such painful stories are "resocialized" through analyses to illuminate issues of structural violence. In the sorts of works I've mentioned, the family stories are clearly historical, speaking to structural issues; the stories from India about my grandmother $\mathrm{Ba}$, though, are partly historical, indexing gender inequality and kinship practices, but also evoking a realm of mythology, legend, and divine power.

\section{MYTHOLOGICAL FRAMES}

Perhaps the publication of my memoir, My Family and Other Saints (2007), was among the reasons that Chanda-phui had asked that we travel to Ba's 
village in early 2009; maybe she would have wanted to go anyway, as for years, when I visited from the United States, she and I would often set off on an adventure related to family history. We had traveled to Kutch, the area that Ramji Seth—Chanda-phui's father, Ba's husband, and my grandfather-had been born. We had paid our respect to lineage goddesses in small shrines in ancestral villages, and to caste goddesses in temples on mountaintops. We had visited the ancient caste bard—surrounded by handwritten yellowing manuscripts wrapped in heavy green plastic in the old city of Ahmedabadin order to gain further explications of the myths and legends his son had performed in Chanda-phui's living room on the new side of the city. We had visited elderly relatives knowledgeable in caste histories in their apartments in Mumbai. The main reason that Chanda-phui had given me for wanting to visit Ba's village in January 2009, though, was that she was eighty years old, and that all her life she'd wanted to see her mother's village.

"Ba never took us," Chanda-phui plaintively said, speaking the Gujaratiinflected Hindi she regularly used for her half-American nieces and nephews. "I never knew if I had uncles or cousins or anything. She used to say that Dakins-powerful witches-live in her village and that's why she wouldn't bring her children there. She said that she could handle those Dakins but that it was too dangerous for us."

"Ba aisi hi thi; that's how Ba was!" Chanda-phui's sister-in-law, Pramilaben, nodded with affectionate recognition of Ba bragging about her prowess against witches.

Ba had died in 1987, but with this story, recounted twenty-two years later, her feisty presence sprang into our company. I could imagine Ba speaking to Chanda-phui in her Kathiawari region's Gujarati, her nasal voice emphatic, and tattooed blue dots flashing along slender forearms as she dramatized her words with dramatically splayed fingers. I listened intently, storing away Chanda-phui's words to later write down in English. Having taught courses on anthropological life histories, I knew how people's self-narrations often cluster around recurrent themes, and Ba had loved telling of how she fearlessly interacted with deities and supernatural forces, and how she had been granted special blessings. When Ba was still alive, I'd written down some of her stories and in my family memoir I'd reproduced many.

The patrilineal caste that most of our relatives claimed was Kutchi Gujar Sutar, carpenters and builders of Kutch. They claimed descent from Vishwakarma, architect of the gods, and many women—not just Ba—would proudly state, "We are the sons (putra) of Vishvakarma!" Kutchi Gujar Sutars sometimes married across the Gulf of Kutch, to the peninsula of Kathiawar: taking daughters from the usually less prosperous Kathiawari Gujar Sutars, they rarely gave daughters in return. Ba was one of these in-marrying Kathiawari 
wives. In the privileging of patrilineal ties, I'd grown up without thinking it strange that we didn't know Ba's siblings except for her older sister, Maushi, who spent her old age lovingly embroidering huge hangings with scenes from the life of Krishna. Krishna was Maushi's chosen God. Ba, though, often alluded to her special relationship with Shiva: powerful ash-smeared Shiva, with his matted locks, crescent moon on his forehead, a serpent round his neck; Shiva sitting on a tiger skin on Mount Kailash with tremendous powers of meditation and a third eye that could burn an offender to ashes; Shiva savoring the fierce beautiful Goddess companionship of his consort Parvati; Shiva periodically dancing wildly, in a halo of flames (cf. O'Flaherty). Among the many representations of gods, goddesses, and gurus Ba kept in worship, each morning she placed bilva leaves and fragrant flowers on the agate Shiva lingam set in a silver base and encircled by a silver cobra whose outstretched head served as a canopy.

Slender and straight-backed, with narrow wrists and high arches, Ba had been known for her unusual wheat-skinned beauty in her youth. Even as a widow who dressed only in white saris, she comported herself with a regal air. She was sharp-tongued; inventive in mockery and in curses. Her name had once been "Kadviben," Bitter Sister, she said, on account of having been born at a bitter time when her family had been camped out with other villagers in the jungle on account of a plague. Her father was a carpenter who specialized in bullock cart wheels. Speaking of her girlhood, Ba recalled the many hours she was required to grind grain each morning. But she far preferred telling of the special blessings she'd received from an old man with a face of light who she identified as Dattatreya, Guru of the Gods, whom she'd met under a blossoming white tree when out grazing goats.

As a teenager, Ba had been married off to Ramji Seth, a carpenter turned wealthy contractor almost forty years her senior. The family story recounted "she was sixteen and he was sixty," but she herself vaguely said she had been about eighteen. Marrying Ramji Seth, she took on the name "Kamlabai," Lotus Woman, and left her village life for good. She moved to his city home in distant Bombay before he bought large tracts of land with fields, and built her a mansion in the pilgrimage town of Nasik. Here, she gave birth to seven children, of whom four reached adulthood, and among which only Chandaphui was still alive. Staring at a photograph of Ba, Ramji Seth, and five children reprinted in my memoir, Chanda-phui said in a low, reflective voice: "Everyone else in this picture is gone but me."

Ba was Ramji Seth's fourth wife; his earlier wives, she said, had died on account of his powerful Mars placement, but since hers was just as strong, she had survived. He had been ill when they first married, she said, but thanks to blessings that she had received, he recovered. She loved telling the story 


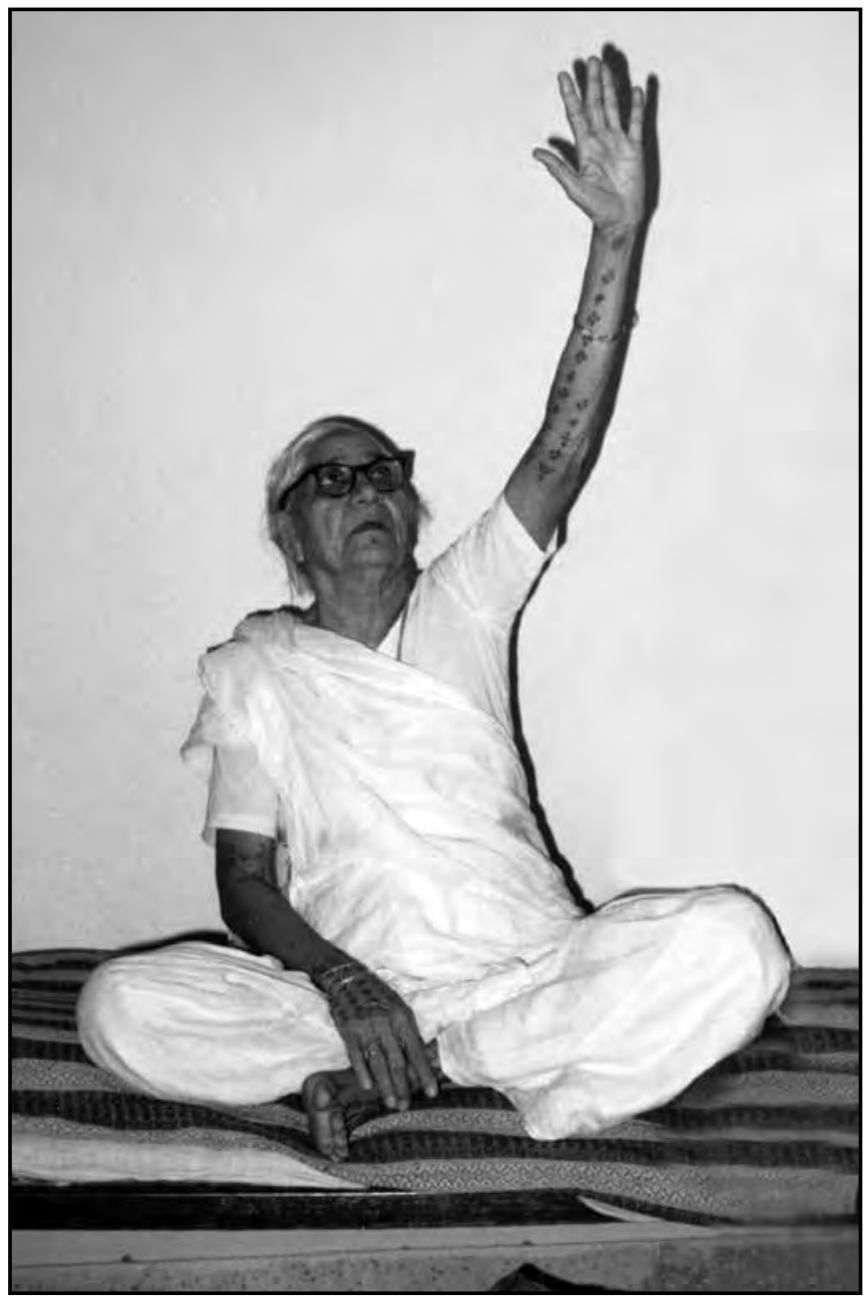

Ba dramatizing how tall Shiva was when he blessed her in the Nasik fields (photo by Kirin Narayan).

of the white cobra who led her from the rooms she shared with Ramji Seth and took her deeper into the fields, where she was enraged to see an animal in the crops, but then realized that this was Nandi, Shiva's white bull. Shiva appeared too, very tall and bright, and had blessed her.

Those fields that Ramji Seth had bought in Nasik contained a well, Ba said, in which there was treasure. The white cobra lived in the well, and a woman warrior had once lived in that well too: the daughter of the Divan, or Prime Minister of a previous Peshwa state, who liked to dress up in men's clothes and go to war on a horse. According to $\mathrm{Ba}$, the amazing treasure of 
gold, silver, and gems now guarded by the white cobra had been amassed by this girl. She knew all this thanks to a medium she'd called in. One of her long-term projects was to get her hands on this treasure.

When $\mathrm{Ba}$ told stories like this to us, her half-American, city-born, cosmopolitan grandchildren, the sense of disparate cultural logics was deliciously heightened. In Life Stories: The Creation of Coherence, Charlotte Linde has written about the different explanatory systems at work in self-narrations, and for Ba life events could usually be explained by powerful and unseen forces to which she had special access. With a pacing simultaneously matterof-fact and dramatic, she described gods giving audience in disguise, goddesses appearing in dreams, planets asserting their forceful presence, ghosts hiding in trees, and all the special forms of propitiation and exorcism that could grant protection. She embodied what the psycholanalyst Alan Roland, writing from clinical experience, discerns as a "mythic orientation" that serves to contextualize the Indian sense of self through folklore and mythology (96-97, 253-54).

Even as a child, I was entranced by Ba's stories and the mysterious, enchanted world they opened out around what was visible. Discovering cultural anthropology and folklore, I found a reason to collect such stories: returning from college in the United States, I'd written down what Ba had to say even though, at the time, I wasn't sure what I'd do with it. Years later, I ended up finding a place for Ba's stories in my family memoir of transnational seeking, My Family and Other Saints. I also drew on a legend that Ba enjoyed telling about Ramji Seth's grandfather to reflect, as a scholar, on how family legends claim status, perform kinship, serve as a form of moral instruction, personalize cultural geography, and might indeed direct our choices of research topics ("Legends").

When Chanda-phui said she wanted to visit Ba's village, then, I happily concurred. With friends' help, I rented a car and driver to take us from the city of Ahmedabad towards Kathiawar, in the west. But though we knew the name of Ba's village, we weren't quite sure where this was. Apart from the detail of the witches, the only thing that Ba had stressed to Chanda-phui was that after her marriage to my grandfather, she had sent funds to the village for the building of a Shiva temple.

To locate the village, Chanda-phui mobilized a larger network through cell phone. Through Ba's sister Maushi's great-grandson, a welder in Ahmedabad, we contacted a grandson who was a carpenter and who still lived in a different small town that Maushi had been married into. As Chanda-phui made the arrangements, I suggested that I could put her and Pramila-ben up in a hotel. She responded: "When you have relatives, you never go to hotels." 
The next morning, Chanda-phui, Pramila-ben, and I set off on our quest, wrapped in shawls against the winter cold. Our relative, a carpenter called Prabhudasji-bhai, was expecting us in the town a few hours away from Ba's own village of birth.

LEFT TO RIGHT: Chanda-phui, Kirin, and Pramila-ben (photo courtesy of Kirin Narayan).

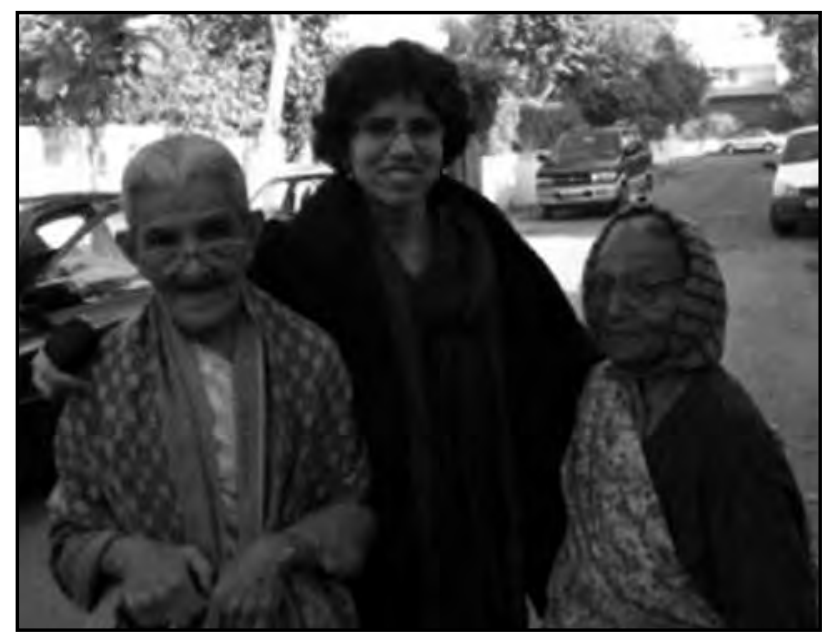

\section{HISTORICAL FRAMES: THE POWER OF DOCUMENTS}

In their wonderful overview, Reading Autobiography: A Guide for Interpreting Life Narratives, Sidonie Smith and Julia Watson point out how family reunions can be a form of ritual for preserving collective memory, as "people gather to remember, reenact, and reaffirm the family's collective past" (17). Indeed, sitting together in the enclosed space of a small white car as we drove west along recently built highways, Chanda-phui and Pramila-ben ran through all kinds of reminiscences for my benefit. Though the relations between a man's wife and his sister are stereotypically tense in most North Indian kinship systems, Chanda-phui and Pramila-ben were close friends. They had been related for almost sixty-five years, growing older in the companionable shade of each other's presence. They had leaned on each other through the difficulties of leaving Karachi for India at Partition in 1947, and then the wrenching losses of parents, husbands, and siblings. In conversation, their words tended to grow together, intertwining and overlapping.

"I wanted to study more but I wasn't allowed to," Chanda-phui fiercely observed from the passenger seat of the hired white car as highway whipped by.

"I never liked to study," said Pramila-ben from the back seat beside me. "I didn't want to study but I loved to learn how to make things."

We were driving along a recently made multilane highway with tollbooths and an astonishing number of temples built in what appeared to be recent bursts of Hindu piety. At the tollbooths, men and children thrust wild bor berries through the windows. Chanda-phui, who had always loved gathering and sharing snacks, amassed small, large, green, and red varieties of berries in 
the lap of her sari. She sliced at the berries with a pocket knife and offered around tastes. Energetically sampling the assorted flavors with strong, toothless jaws, Chanda-phui once again embarked on the story that I always found distressing: how after her Gujarati medium primary school, her father had said it wasn't seemly for a big girl to go across town to study more. She didn't have to point out the contrast to her older brother, who had been sent to an English-medium school, to college in Bombay, and then off for an engineering degree in America. This was my father.

From the back seat, speaking almost simultaneously, Pramila-ben recounted the things she'd enjoyed making over studying. She held up a tote bag lying between us, made from synthetic gray trouser material. "Any piece of cloth that's left over, I'll make something from it," she said.

I tried to be attentive to both conversations, thinking of how I'd had the good fortune of enjoying studying and making things, especially texts. I also thought backward to Ba, for whom, as a village carpenter's daughter in the early twentieth century, school had never been a possibility. "I might be illiterate but that doesn't mean I have no brains," had been one of Ba's favorite sayings as she became a city matron, married to an older and wealthier man: when she contended with an American daughter-in-law and a different set of cultural expectations in her very own home; when she encountered all the strange marvels of technology unfolding through the twentieth century. On the other side of these generational differences, I had not only gone to school but had received a $\mathrm{PhD}$ : this shift in educational possibilities across three generations was due partly to an ascent in class status, the family's migration from village to town to city, the unexpected new ingredient of a foreign daughter-in-law, and widening opportunities for educating women all over India through the twentieth century. Now Ba's stories had been carried forward from a largely oral environment into diasporic writing through my family memoir, and were perhaps out meeting new audiences through print.

Traveling west from Ahmedabad to Kathiawar for the first time, I recalled Mira Kamdar's visit to her own grandmother's village in Kathiawar in the first part of her memoir Motiba's Tattoos: A Granddaughter's Journey into Her Indian Family's Past. Kamdar's paternal grandmother, Motiba, was roughly of $\mathrm{Ba}$ 's generation, though from a wealthier Jain background. Like Ba, she carried dark blue tattooed patterns on her forearms, the back of her hands, and chin. For Kamdar, stories about Motiba initiate a stream of reflections about the distinctive cultural character of the region, and changes since the early twentieth century. Her intent in following her family's stories is less to linger on the potential drama or interactional dynamics of these stories than to retell facts and expound on the changes in India and the world generally through the twentieth century. As she writes, "The story of my grandmother's life and 
the lives of her descendants is the story of leaving home, of losing one's tribe. It is the story of diaspora, of the transition from rootedness to rootlessness, of moving until you no longer know who you are and have forgotten who you once were" (xxiv). Part of Kamdar's reclaiming of the past and of identity is through building on family stories through research and travel.

As we too drove towards our village destination, Chanda-phui and Pramila-ben reminisced about Ba's stories of meeting gods and of the quest for treasure. I greeted these stories like old friends, and also thought of how the social life of transmitted stories masks silences: both the culturally inflected silences around what's not story-worthy and the intentional personal silences of keeping family secrets ("Honor"). Writing my memoir, I was constantly aware of what I was leaving out, either because it didn't fit the theme, or because I was attempting to be diplomatic. In particular, staying close to the theme of transcultural religious quests and a time period of the late $60 \mathrm{~s}$ and early 70s, My Family and Other Saints had passed over a powerful story about Ba. This was a story that she never told herself, and which I only came to know years after her death in 1987.

In 1999, I was rummaging through trunks of family papers that included papers found in Ba's safe after her death. I was startled to find Ba's divorce papers. My mother knew of this divorce; other family members had known too, but no one had ever talked about it. These divorce papers weren't actually generated at the time of the divorce in 1923. Instead, the papers had been produced as a set of signed affidavits for the 1936 "High Court CCCJ Suite 1836, Vasanji Ramji Plaintiff vs. Ramji Keshavji and others, Defendants." Vasanji Ramji, the plaintiff, was my grandfather's son by an earlier marriage who filed this case a few years after his father Ramji Keshavji had married the much younger Kamlabai, or Ba.

The affidavits appeared in Gujarati with English translation. A man named Pitamber Jairaj of Zinzri in the princely state of Junagadh and "a Hindu inhabitant working in Mahaluxmi Mills, Bhavnagar," acknowledged he had once been Ba's husband, marrying her in approximately 1916:

Abt 20 years back I was married to Bai Kamlaben alias Kadvi the daughter of Hirji Velji [Tricumji crossed out]. My marriage w/ the sd. Kamlaben was not happy. Disputes and differences arose between us, and ultimately with a view to put an end to these disputes I applied to my caste to have my marriage with Kamlaben dissolved. According to the custom of the caste on my application, a notice was sent around to the members of the caste for convening a meeting of the members of the caste to decide the said question. ...

Note the emphasis on religious identity and caste custom for the colonial British law courts in Bombay. According to this document, the meeting of all 
the male caste elders was held on October 7, 1923. Pitamber Jairaj and his father presented their complaint. Ba was not listed as present, but was represented by her father and brother. Pitamber Jairaj's affidavit continues:

My complaint was investigated by the members of the caste and after both the parties the members of the caste decided to dissolve my marriage with Kamlaben and directed that the sd. Hirji Velji the father of Kamlaben should pay to me a sum of Rs. 300/- or thereabouts and that in consideration thereof I should pass a Fargati (resolution) in favor of Kamlaben releasing all my claims as a husband against the said Fargati.

The paper concludes with Pitamber Jairaj of Zinzri attesting that according to custom, after this resolution, both were "free to marry again and any children begotten are considered legitimate and can inherit property, etc." I do not know exactly when Ba remarried, but after one stillbirth, my father was born in 1927, the eldest son of Ba's second marriage. In 1936, then, he was nine years old, with three younger siblings. With Pitamber Jairaj's testimony, Ba's children's right to inheritance was affirmed. While these court documents might seem to contain the actual facts of Ba's life, given that the papers were drawn up years later, it's hard not to wonder about the circumstances under which they were manufactured, and the role of Ba's more powerful and wealthy second husband in persuading Pitamber Jairaj to grant his testimony.

After these legal proceedings, my grandfather's elder sons received a share of property but always lived separately. My own childhood was spent in the traumatic aftermath of this split between the sons of Ramji Seth's earlier wives and the sons of $\mathrm{Ba}$. When the court case was mentioned, it was always described as being about property, never divorce or legitimacy. Ba told us that this case had gone well because she had stopped to pay respects to a sadhu or holy man while driving to Bombay for a court appearance. This sadhu by the side of the road, she said, had revealed himself to actually be Lord Shiva, serpents crawling all over his arms (graphically represented by her squirming long fingers). For $\mathrm{Ba}$, triumph always had a mythological tinge.

\section{NARRATIVE INTERSECTIONS}

Our day of driving took us past Mount Girnar, a strikingly shaped volcanic mountain sacred to both Hindus and Jains. We continued through the city of Junagarh, where we stopped to buy special winter sweets. The twisting trunks of giant old trees lay toppled along the route, presumably making way for widened roads. We passed towns and tea stalls, and men wearing long stocking caps that had replaced white turbans. 
Our relative through Ba's sister, Prabhudasji-bhai, came out to the main market of his small town to meet our car and lead us through narrow alleys towards where his family lived. He knew the way to the village where both $\mathrm{Ba}$ and his grandmother had been born, but he said it was too far to go onward that evening. Instead, we visited a local shrine to the Goddess Randal Ma, the daughter of Vishwakarma, creator of the universe, from whom hereditary artisans and builders claim descent.

Sitting in the main room of our relative's home before the blurry television news footage of the soon-to-be inaugurated new President Obama, Chanda-phui reflected on the day, recalling other family stories. She unexpectedly announced. "My mind is slipping. I forget things. It's better to forget so you don't burn up over the past."

"I forget things too," Pramila-ben commiserated.

Taking notes in my journal, I wondered what $\mathrm{Ba}$ had forgotten and walked away from, that we had never been told.

The next morning we enjoyed generous hospitality from our newly found relatives-hot milky ginger tea, bucket baths, glistening parothas - and then we set off with Prabhudasji-bhai guiding the driver. Passing towns and fields and new electric facilities, we reached a village with a sign reading Untadi, just as Ba had said. We turned inward towards a settlement. Chanda-phui asked a passerby the directions to the Mahadev temple, and we parked by the gate.

Chanda-phui at the door of the temple (photo by Kirin Narayan).

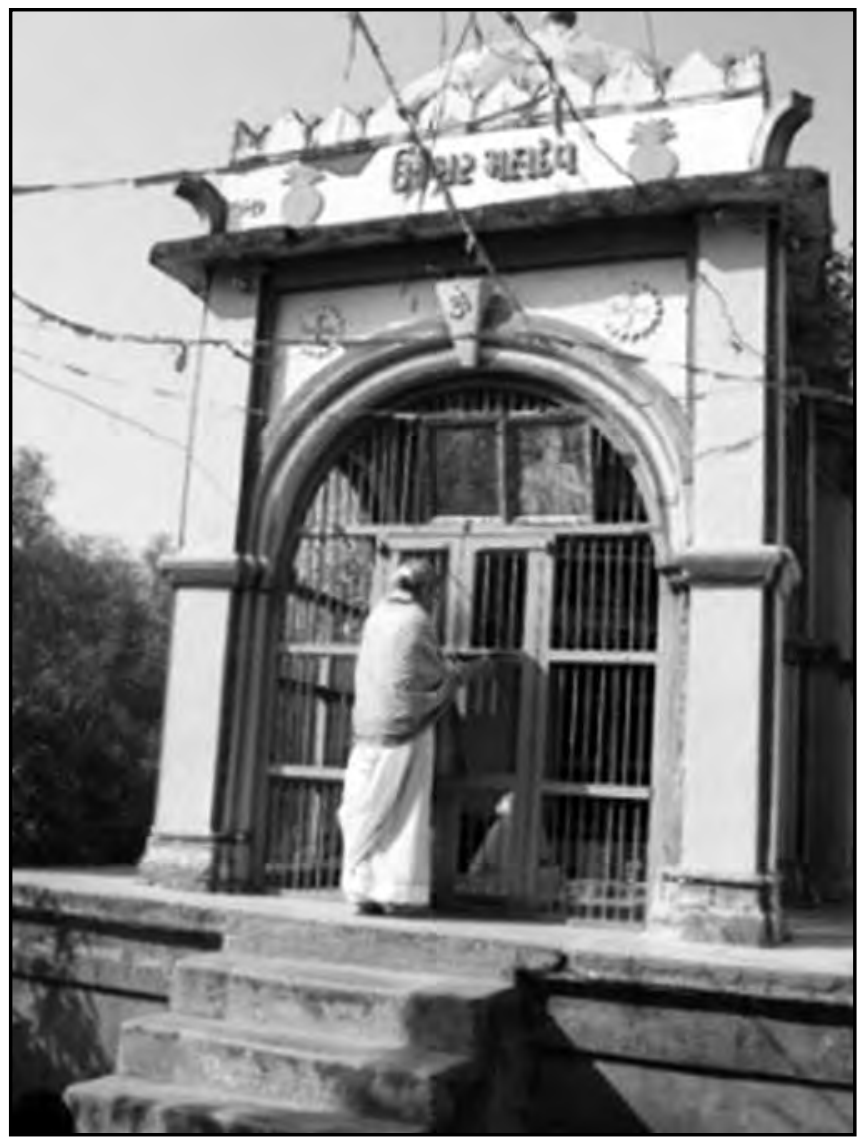


"This is the temple that Ba sent the money for," said Chanda-phui with satisfaction as we entered the temple grounds. The sun was reaching its midday heat and the small temple shone with bright colors: blue, green, and white. "Unteshwar Mahadev" was emblazoned in Gujarati above the entrance. This could mean Shiva as Lord of the village Untadi, and also Lord of Camels. Chanda-phui purposefully strode forward, unlocked a grill, and motioned for me to join her. Pramila-ben, who had trouble walking, lingered behind.

No Brahman pujari was present as we viewed Shiva in the form of a black stone lingam hooded by a copper serpent-the image echoing the silver lingam and serpent from Ba's puja that was now on my altar in Madison. We joined our palms and offered some money. I paused to take a photograph or two. When I turned around, I saw that a man with graying hair had appeared, settled down in a little shed on the property, and begun talking. I came over to find Prabhudasji-bhai, Chanda-phui, and Pramila-ben all crowded around him animatedly speaking in Gujarati.

"What he's saying is this," said Pramila-ben, pulling me aside.

This temple was built by a girl called Kadviben. Her husband had died and she was so distraught, she jumped into the well to die. But she lived. Now that she had lived, she prayed to this god: "If you save me and if you find me a

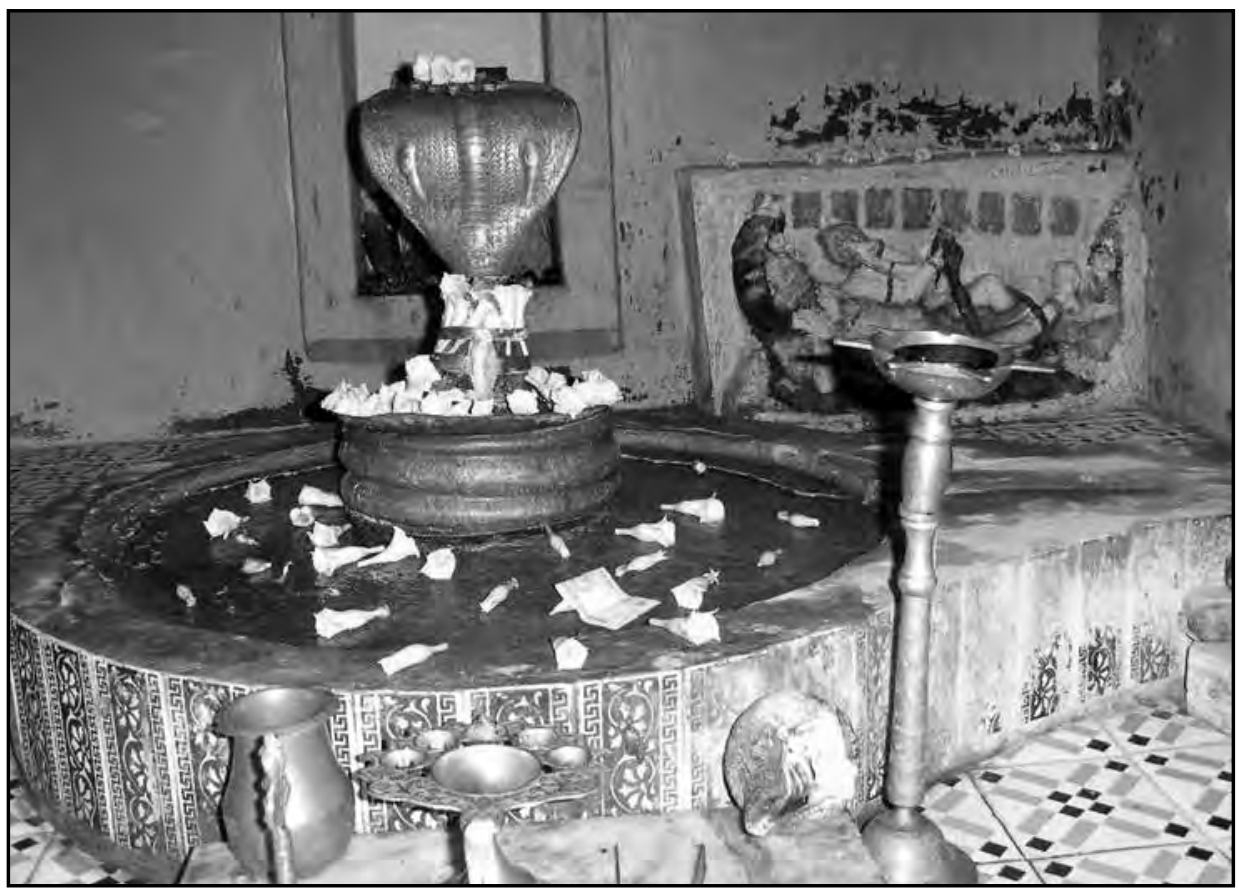

Lord Shiva as Unteshwar Mahadev (photo by Kirin Narayan). 
good home to marry into, I will build you a temple." Then she was saved and she was married to a Seth from Nasik. After this, she built the temple.

"Kadviben, that's Ba!" I exclaimed. I immediately guessed that it was more respectable for the newly unattached young woman in the story to be a widow than to have broken off a relationship with a husband.

"That's Ba's story," agreed Pramila-ben.

Chanda-phui looked around. "Why did she never tell us this?" she asked with a note of strain in her voice, clearly distressed and bewildered.

"How could Ba tell such a story?" Pramila-ben murmured in my ear. I understood that $\mathrm{Ba}$, who'd never liked to show vulnerability of any sort, might not have chosen to include this particular story in her favored repertoire of tales about special visitations and blessings from gods, goddesses, and holy people.

But where was the well? The man went on to explain that the well had dried up and had now been filled over. He gestured at an open field, where cow dung cakes lay drying and a white bird strutted. At the time that they filled up the well, they also pulled out another stone lingam, he said, and this was housed in another shrine beside the main one. I went over to photograph this shrine too.

By this time other men had arrived to investigate the visitors in the white car. Our claiming a connection to the temple seemed to transform us into almost unreal figures arriving from the mists of a legend. An old man in a loose white stocking cap who lived nearby urged us to drink tea; the village headman in a white safari suit and wearing sunglasses told us of plans to expand a kitchen for pilgrims. We asked after the descendants of Ba's brothers, and were told that this carpenter had had an accident with his thumb and had been taken off to a hospital. (Looking back, and considering the wider life of an extended family, I wondered if this emergency kept all members of that household away from us, or whether perhaps some stigma or shame still lingered).

We were settled down in a room with an enormous bed crowding out most of the space and chairs lined up along the walls. Perching at all angles, we drank tea poured the Kathiawari village way from a kettle directly into saucers, vividly evoking how Ba always tipped tea from a cup into a saucer before sipping from its edge.

Led by our male hosts along narrow cemented paths to see Ba's old home, Chanda-phui stopped to speak to everyone we passed, energetically introducing herself as the daughter of Kadviben from this very village. I trailed after, camera in hand. Old women sitting on mats in the sun reached up to embrace Chanda-phui. I wondered if it would have been their mothers-in-law, or their grandmothers-in-law, who Ba might long ago have seen as her disapproving adversaries, the dangerous "witches." 
We passed courtyards where cotton was being stored in big bales, and sheds with great sacks of peanuts. Finally, we paused before the exterior walls of a low mud house. We entered, finding a small courtyard and what appeared to be two or three rooms. Tenants now lived here, but a small faded and framed poster of Vishwakarma on a wall was a reminder that this mud home belonged to artisans. Standing in the courtyard, I stared at the crowded area with pots and buckets of water, and thought of $\mathrm{Ba}$ as a girl squatting to wash dishes long ago, before an adjoining cement building loomed into that view. In the Nasik mansion that Ramji Seth had built for Ba, two stories were set in a U-shape around a courtyard, but a small space with pots and buckets of water had been set aside for dishes near the kitchen. Never once had I ever seen Ba washing dishes, though: she had always enjoyed having servants wash dishes for her. Perhaps, I thought, Ba had never wanted her new family to see her old lodgings because the small, cramped space didn't fit her grander new identity.

I was busily documenting our visit with a camera. But on our way back to the car, the headman arranged for the schoolteacher, who was writing a history of the village, to document our visit too. The teacher, a young man with dark curls and what appeared to be betel nut lodged in a cheek, squatted on a raised ledge under a tree, his notebook in hand. "Tell me what happened to Kadviben," he asked Chanda-phui.

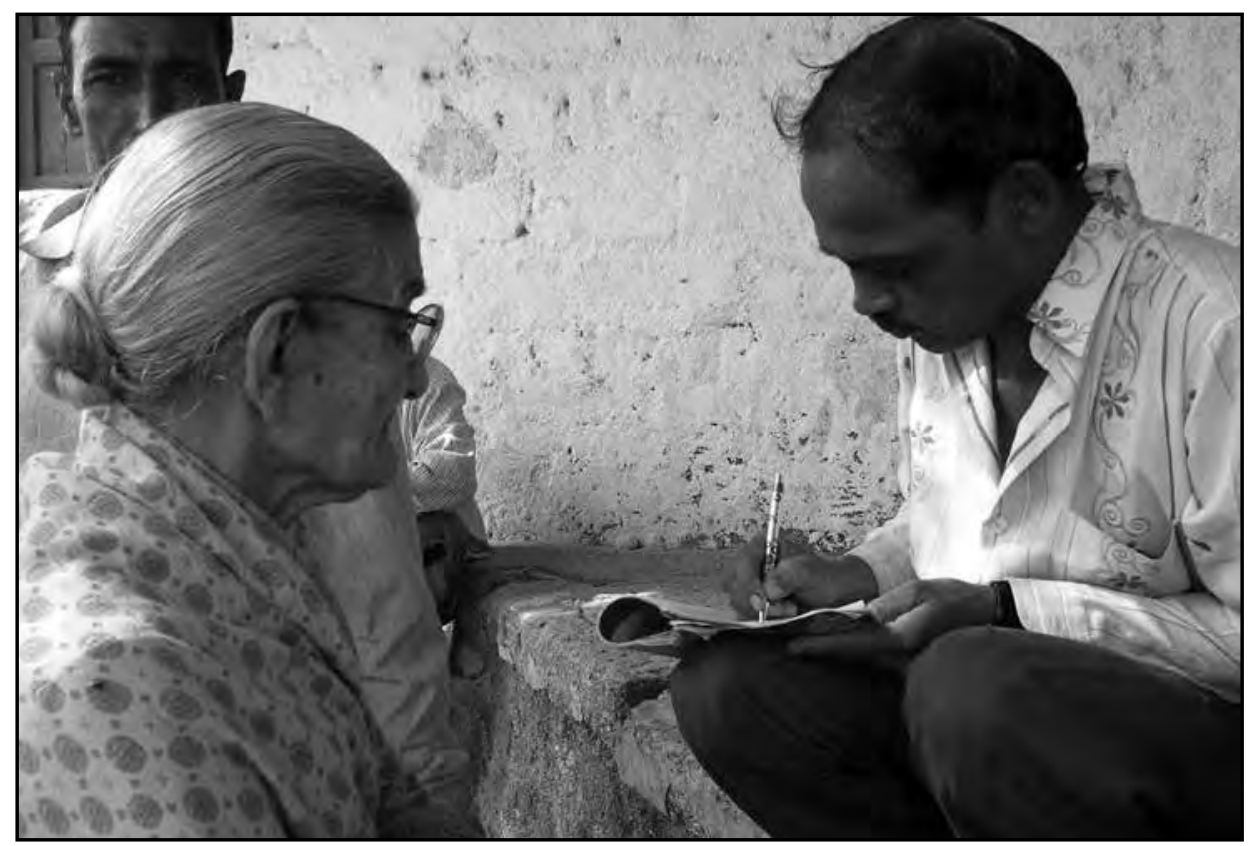

Chanda-phui provides family history for the village historian (photo by Kirin Narayan). 
Shawl wrapped tight around her shoulders, chin raised to peer through her bifocals, Chanda-phui instructed him on the highlights of what had happened since that rebellious young girl had been granted her boon and left the village. Chanda-phui recited the names of Ba's children, grandchildren-even ones in America! - great-grandchildren, and beyond. The man carefully wrote down these events as part of the history of the temple. Even as we were taking in this village as a setting of our family stories and secrets, then, we ourselves were being appropriated as indisputable proof of the power of the local deity, Unteshwar Mahadev.

\section{CONCLUSION}

What can we make of the powerful orally transmitted stories that we receive as members of families? Such stories aren't usually about our own lives, but they hang solidly in an intersubjective space, reorienting our understandings of others and ourselves. They can join our self-narrations, becoming a means to explicate identity and reframe heritage; they can even find the fixity of a written form. Memoirs regularly appropriate such tales as aspects of selfnarration; novels that build on such tales usually hide their roots. With the steadily growing acceptance of reflexive approaches, scholars encountering such family stories have increasingly been able to bring them into a scholarly arena: measuring, shaping, and building these into texts with disciplinary tools.

A hopeless woman jumping into a well may remind you of the searing first chapter, "No-Name Woman," in Maxine Hong Kingston's ChineseAmerican memoir The Woman Warrior: Memoirs of a Girlhood among Ghosts. "You must not tell anyone ... what I am about to tell you" (1), Kingston's mother warns before recounting the story of Kingston's father's sister, who became pregnant too pointedly long after her husband had left for America. When the pregnant aunt was due to deliver, fellow villagers wearing clay masks arrived in a mob at the house: killing animals, overturning food jars, destroying property, shouting insults. The aunt gave birth in the pigsty that night and then threw herself and her newborn infant into the family well. After her death, her family too participated in her punishment through silence. But as Kingston writes, commemorating her aunt's existence, "Unless I see her life branching into mine, she gives me no ancestral help" (8).

$\mathrm{Ba}$ has given me ample ancestral help through her forceful presence, rebelliously unbowed by patriarchal structures around her. This story that recounts a despair so fierce that she sought to end her own life seems strangely uncharacteristic. Already on the drive back to Ahmedabad, Chanda-phui was questioning what we had learned. "Ba would have argued with people, she 
wouldn't have gone jumping into a well," Chanda-phui said, "This must be some other Kadviben."

"Who else would this have been but Ba?" Pramila-ben muttered, poking me in the back seat.

"But Chanda-phui, she was just a young girl then," I sat forward to enunciate. "She wasn't yet Ba."

Later, speaking to me by phone, Chanda-phui has often repeated that she can't believe this story about her mother. She wants to go back sometime and talk to more people. She says she received a call from Ba's brother's grandson, and that someday he may come to the city to visit her. She says she's still waiting for the village historian to send her a copy of his book.

Other family members have met my revealing of this story with astonished silence-or is it an embarrassed silence that I am airing an uncomfortable secret, telling openly of a divorce, of an attempted suicide, and also exposing what clearly appears to have been Ba's rift with her father and brothers? One relative of an older generation, though, has hinted at the larger life of family stories that remain unspoken. Tantalizingly, she's dangled the possibility of knowing far more than she lets on: "I could tell you so many things. But I'm not going to say anything, otherwise whatever I tell you'll just go and write."

"But what if I write a novel?" I responded, abashed in being called out for having already published a family memoir. "A novel so nobody can be recognized?"

"My Mummy used to say ..." this relative began, circuitously hinting at a few more details. But having given my word of honor that I wouldn't write this up as nonfiction, I hold back from revealing more about Ba's move from the village to become the wife of Ramji Seth.

Does it matter if this legend of Kadviben and Unteshwar Mahadev is true or not? It still dramatizes how arranged marriage determined a girl's life in Ba's generation, her outsiderhood in her own father's home, the desperation of nowhere to go, and how the agency of the powerless is sometimes most safely expressed as supernatural intervention. Thinking more closely about the story, I also see in it a mosaic of themes from the stories that Ba did tell: of her special relationship with Shiva and the boons granted through his blessing; of the woman warrior who lived in a well and emerged for warfare; of the treasure that the woman had amassed that was now guarded by the white cobra associated with Shiva.

Ba's spirited storytelling is for me a treasure that has become part of my own imaginative possibilities for women's power even in the most narrowly confining of situations. As someone who is shy, even talking of Ba energizes 
me into mimicking her through performance. I retell her stories orally and through writing, always savoring an enhanced sense of mystery.

A story of this sort cannot be full-fledged ethnography. I know little about Ba's village beyond our morning's visit. I do not know the village's social or political conditions, or the repercussions of the devastating anti-Muslim riots and brutal violence in Gujarat in 2002. It would take me many months of reading and of fieldwork to write with authority about this local setting in the past or the present. The family story, though, leaps into action across time and regions into a different framework of kinship-based narration and self-narration.

In its very compactness, the story of Kadviben tantalizes me to elaborate: if not through the frames of nonfiction, then by being appropriated and recast from within. Here are the images glinting into my imagination as I consider the pretty, slender girl with a stubbornly set mouth and tattooed dots along her arms: Kadviben, who was not yet Kamlabai or Ba. I wonder if I will ever have the nerve to follow this story into the bracing medium of fiction. I think of all the ethnographic and historical research I would need to do to make this convincing, and yet . . that young girl reflects upward from the long-gone well:

She surfaced, her body still shocked by the impact and the cold, her eyes adjusting to the half-light so far below the ground.

"Go jump in the well," her brother had said, still grudging her the 300 rupees their father had been forced to pay caste elders to bring her home. She struggled to the well's inner edge, her movements magnified by echoing water. Grabbing at a protruding brick, she felt the green slime, but her hand didn't slip. She rested in the quiet, after all the shouting, the shame.

Looking upward, beyond the spatter of wetness from her own hurtling body, she saw occasional tufts of grass that had taken hold between pieced bricks, and far away, a silvery coin of sky. She reached for the next, higher brick protruding in a slow spiral along the well's edge. Secured with ropes, men would have climbed down these bricks to retrieve her bloated body, a circle offaces peering from the well's edges. But instead, here she was, life pulsing and tingling.

She rested another minute and turned her mind to Shiva in the open shrine high above her, on the ground beside the well.

"If you get me out of here and give me a good home, I'll build you your own temple," she said.

Then she began climbing sideways towards the sky that stretched far beyond this village. 
That upward climb made possible the widening horizon of a new life with a new name and an identity that didn't need to look backward. That upward climb also made possible a new family, and new family stories: those told, those written in different sorts of texts, and those hidden away as partially revealed secrets.

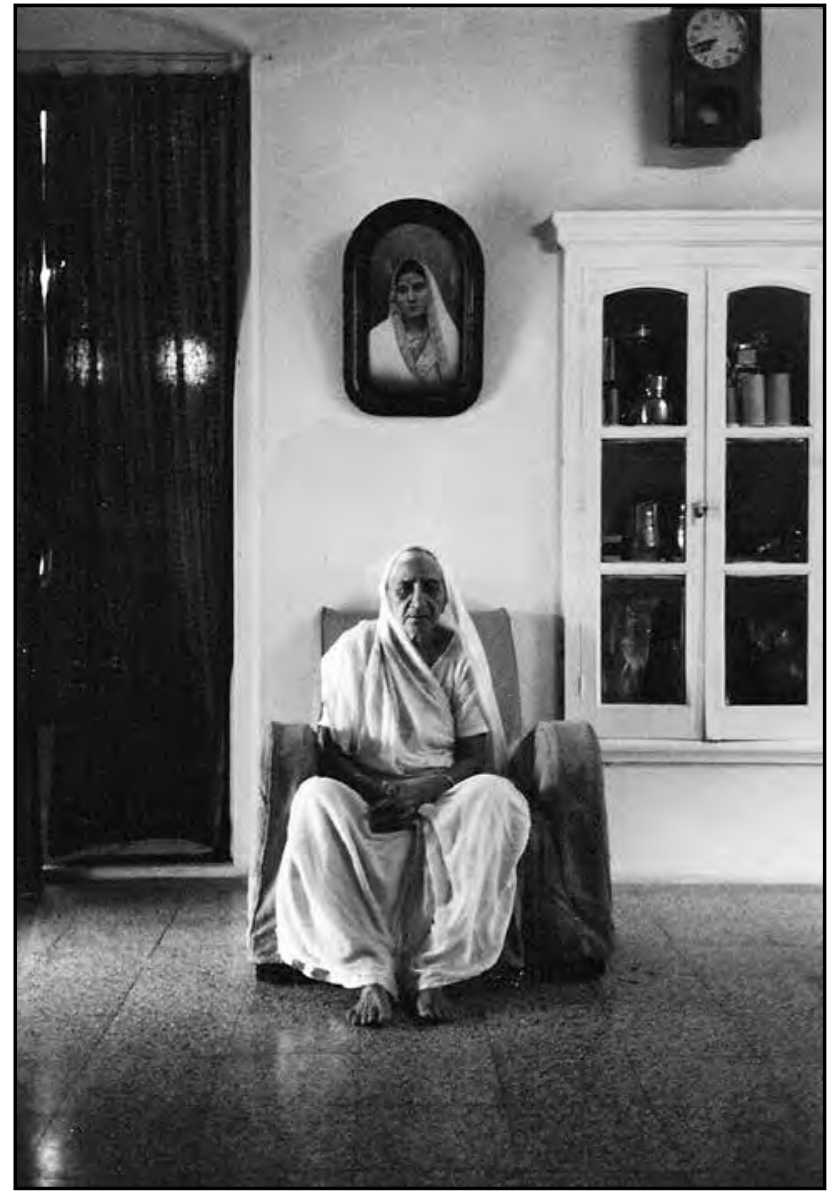

Ba telling stories of her girlhood (photo by Kirin Narayan).

\section{ACKNOWLEDGMENTS}

I thank Maureen Perkins, Craig Howes, and Peter Read for the invitation to a wonderfully stimulating conference, all participants for their presentations, comments and questions that helped shape this essay, and Stanley Schab for his gracious handling of the editorial process. I also thank Ken George, Didi Contractor, Maria Lepowsky, Sankaran Krishna, Tara Contractor, Anne Haggerson, and Jeanne Thieme for their generous reading of various drafts of this essay. 


\section{WORKS CITED}

Abu-Lughod, Lila. "Returning to Half-Ruins: Memory, Postmemory and Living History in Palestine." Nakba: Palestine, 1948, and the Claims of Memory. Ed. Ahmad H. Sa'di and Lila Abu-Lughod. New York: Columbia UP, 2007. 77-104. Print.

Bateson, Mary Catherine. With a Daughter's Eye: A Memoir of Margaret Mead and Gregory Bateson. New York: William Morrow, 1984. Print.

Behar, Ruth. An Island Called Home: Returning to Jewish Cuba. Photographs by Humberto Mayol. New Brunswick, NJ: Rutgers UP, 2007. Print.

Bertaux, Daniel, and Paul Thompson, eds. Between Generations: Family Models, Myths, and Memories. New York: Oxford UP, 1993. Print.

Bhatnagar, Rashmi Dube, Reenu Dube, and Reena Dube. "A Poetics of Resistance: Investigating the rhetoric of the bardic historians of Rajasthan." Muslims, Dalits and the Fabrications of History. Ed. Shail Mayaram. Subaltern Studies 12. New Delhi: Permanent Black, 2005. 224-79. Print.

Boatright, Mody. The Family Saga and Other Phases of American Folklore. Urbana: U of Illinois P, 1958. Print.

Brandes, Stanley. "Family Misfortune Stories in American Folklore." Journal of the Folklore Institute 12.1 (1975): 5-17. Print.

Farmer, Paul. "The Banality of Agency: Bridging Personal Narrative and Political Economy." Anthropological Quarterly 78.1 (2007): 125-35. Print.

Fiese, Barbara et al., eds. The Stories That Families Tell: Narrative Coherence, Narrative Interactions and Relationship Beliefs. Maldon, MA: Blackwell, 1999. Print.

Kamdar, Mira. Motiba's Tattoos: A Granddaughter's Journey into her Indian Family's Past. New York: PublicAffairs, 2000. Print.

Kingston, Maxine Hong. The Woman Warrior: Memoirs of a Girlhood among Ghosts. New York: Knopf, 1976. Print.

Langellier, Kristin M., and Eric E. Peterson. Storytelling in Daily Life: Performing Narrative. Philadelphia: Temple UP, 2004. Print.

Linde, Charlotte. Life Stories: The Creation of Coherence. New York: Oxford UP, 1994. Print. Morgan, Kathryn. Children of Strangers: The Stories of a Black Family. Philadelphia: Temple UP, 1980. Print.

Narayan, Kirin. "'Honor is Honor After All': Silence and Speech in the Life Stories of Women in Kangra, North-West India." Telling Lives in India: Biography, Autobiography and Life History. Ed. David Arnold and Stuart Blackburn. New Delhi: Permanent Black/Bloomington: Indiana UP, 2004. 227-51. Print.

. "Legends and Family Folklore." The Legend: Conceptual Issues and Pragmatics of Telling. Ed. Kishore Bhattacharjee. Spec. issue of Indian Folklife 25 (Jan. 2007): 4-7. Print.

- Mondays on the Dark Night of the Moon: Himalayan Foothill Folktales. With Urmila Devi Sood. New York: Oxford UP, 1997. Print.

My Family and Other Saints. Chicago: U of Chicago P, 2007. Print.

- Storytellers, Saints and Scoundrels: Folk Narrative in Hindu Religious Teaching. Philadelphia: U of Pennsylvania P/Delhi: Motilal Banarsidas, 1989. Print. 
Narayan, Kirin, and Kenneth M. George. "Interviewing for Folk and Personal Narrative." Handbook of Interview Research: Methods and Context. Ed. Jay Gubrium and James Holstein. New York: Sage, 2001. 815-31. Print.

O'Flaherty, Wendy. Asceticism and Eroticism in the Mythology of Siva. London: Oxford UP, 1973. Print.

Orlove, Ben. In My Father's Study. Iowa City: U of Iowa P, 1995. Print.

Pratt, Michael, and Barbara Fiese, eds. Family Stories and the Life Course: Across Time and Generations. Mahwah, NJ: Lawrence Erlbaum, 2004. Print.

Roland, Alan. In Search of Self in India and Japan. Princeton: Princeton UP, 1988. Print.

Shah, A. M., and R. G. Shroff. "The Vahivanca Barots of Gujarat: A Caste of Geneologists and Mythographers." Traditional India: Structure and Change. Ed. Milton Singer. Spec. issue of Journal of American Folklore 71 (1958): 246-76. Print.

Smith, Sidonie, and Julia Watson. Reading Autobiography: A Guide for Interpreting Life Narratives. Minneapolis: $U$ of Minnesota P, 2001. Print.

Snodgrass, Jeffrey G. Casting Kings: Bards and Indian Modernity. New York: Oxford UP, 2006. Print.

Stone, Elizabeth. Black Sheep and Kissing Cousins: How Our Family Stories Shape Us. New York: Penguin, 1988. Print.

Trujillo, Nick. "In Search of Naunny's History: Reproducing Gender Ideology in Family Stories.” Women's Studies in Communication 25 (2002): 88-118. Print.

Waterston, Alisse, and Barbara Rylko-Bauer. "Out of the Shadows of History and Memory: Personal Family Narratives as Intimate Ethnography." The Shadow Side of Fieldwork: Exploring the Blurred Borders between Ethnography and Life. Ed. Annette Liebling. Malden, MA: Blackwell, 2007. 31-55. Print.

Welland, Sasha. A Thousand Miles of Dreams: The Journeys of Two Chinese Sisters. Lanham, MD: Rowman and Littlefield, 2006. Print.

Zeitlin, Steven J., Amy J. Kotkin, and Holly Cutting Baker. Celebration of American Family Folklore: Tales and Traditions from the Smithsonian Collection. New York: Pantheon Books, 1982. Print. 